\title{
TINGKAT KERJA OSMOTIK DAN PERTUMBUHAN KERANG HIJAU PERNA VIRIDIS YANG DIKULTIVASI DI PERAIRAN TAMBAK LOROK SEMARANG
}

\author{
Osmotic Perfomance Rate and Growth Rate of Green Mussel \\ Perna viridis Cultivated in Tambak Lorok Semarang
}

\author{
Temmy, Sutrisno Anggoro*) dan Niniek Widyorini \\ Program Studi Manajemen Sumberdaya Perairan \\ Departemen Sumberdaya Akuatik \\ Fakultas Perikanan dan Ilmu Kelautan, Universitas Diponegoro \\ J1. Prof. Soedarto, SH, Tembalang, Semarang, Jawa Tengah - 50275, Telp/Fax. +6224 7474698 \\ Email : si.temmy@gmail.com
}

\begin{abstract}
ABSTRAK
Tambak Lorok adalah salah satu perkampungan nelayan yang letaknya berada di pesisir teluk Semarang. Sebagian besar masyarakatnya berprofesi sebagai nelayan, salah satunya pembudidaya kerang hijau. Kerang hijau membutuhkan habitat yang ideal untuk tumbuh dengan optimal. Salinitas perairan memiliki pengaruh terhadap pertumbuhan kerang hijau, karena kadar salinitas yang tidak ideal mengharuskan kerang hijau melakukan proses osmoregulasi yang membutuhkan energi besar, sehingga pertumbuhan terhambat. Tujuan penelitian untuk mengetahui pola osmoregulasi, nilai tingkat kerja osmotik dan laju pertumbuhan relatif serta hubungan antar keduanya pada kerang hijau yang dikultivasi. Penelitian dilaksanakan pada bulan September sampai dengan bulan November 2016 di perairan Tambak Lorok Semarang. Hewan uji yang digunakan dalam penelitian ini adalah kerang hijau (Perna viridis) dengan bobot ratarata 40 gram. Data yang diperoleh dari hasil penelitian dianalisis dengan menggunakan analisis regresi untuk mengetahui hubungan antara salinitas dan tingkat kerja osmotik serta laju pertumbuhan relatif. Pola osmoregulasi kerang hijau adalah hiperosmotik terhadap lingkungannya. Nilai tingkat kerja osmotik kerang hijau sebesar 35,44 sampai dengan 68,03 mOsm/ $1 \mathrm{H}_{2} \mathrm{O}$. Laju pertumbuhan relatif sebesar 133,33 \% sampai dengan 220,69 \%. Tingkat kerja osmotik dan laju pertumbuhan relatif kerang hijau menunjukkan hubungan yang berpola linier bersifat negatif dengan tingkat keeratan tinggi.
\end{abstract}

Kata kunci : Kerang Hijau, Perna viridis, Tambak Lorok, Tingkat Kerja Osmotik, Laju Pertumbuhan.

\begin{abstract}
Tambak Lorok is one of the fishing villages located near the coast of Semarang Bay. Most of the people work as fishermen, who work also cultivate green mussels. Green mussels need an ideal habitat to grow optimally. The water salinity affects the growth of the mussels, if the level of the water salinity is not ideal it will force the green mussels to osmoregulate that require big energy, therefore it will slow the growth of the mussels. The goal of the research was to examine the osmoregulation pattern, osmotic performance rate, and the relative growth rate of green mussels, as well as the relation between osmotic perfomance rate and growth of the green mussel. The research was conducted on September to November 2016 in Tambak Lorok Semarang. The animal that has been used in this research was green mussels (Perna viridis) with the average weight of 40 grams. The data were analyzed using regression analysis to study the relations between salinity, osmotic perfomance rate and relative growth rate. The green mussels's osmoregulation pattern was hyperosmotic to its environment. The osmoregulation rate of green mussels were 35,44 up to 68,03 $\mathrm{mOsm} / \mathrm{l}$ $\mathrm{H}_{2} \mathrm{O}$. The relative growth rate were $133,33 \%$ up to 220,69\%. The osmotic perfomance rate and relative growth rate of green mussels showed linier relations with high rate and suggested had negative characteristic.
\end{abstract}

Keywords: Green Mussels, Perna viridis, Tambak Lorok, Osmotic Perfomance Rate, Growth Rate.

*) Penulis penanggungjawab

${ }^{\circ}$ Copyright by Management of Aquatic Resources (MAQUARES)

164 


\section{PENDAhuluan}

Kerang merupakan salah satu komoditi hasil perikanan yang memiliki nilai gizi tinggi. Selain mengandung protein hewani yang relatif tinggi, kerang juga mengandung asam-asam lemak jenuh essensial dan mineral yang diperlukan oleh tubuh manusia (Amalia, 2007). Kerang hijau (Perna viridis) ini dianggap sebagai bioindikator yang baik dalam merespon perubahan pada lingkungan. Dilaporkan bahwa kerang hijau adalah organisme yang cocok digunakan dalam studi untuk memantau perairan pesisir karena distribusi geografis yang luas, cara hidup menetap dan mekanisme filter feeding (Putri dan Aunurohim, 2012).

Spesies kerang yang hidup di lingkungan estuari, terutama yang hidup pada sesil dan intertidal, harus memiliki kemampuan untuk mentoleransi kondisi lingkungan yang ekstrim dan dapat berubah berkali-kali dengan cepat (McFarland et al., 2015). Kerang hijau ini hidup subur pada perairan teluk, estuari, perairan sekitar area mangrove, dan muara sungai, dengan kondisi lingkungan yang dasar perairannya berlumpur campur pasir, dengan cahaya dan pergerakan yang cukup, serta kadar garam yang tidak terlalu tinggi (Yonvitner dan Sutrisno, 2009).

Hujan merupakan gejala meteorologi dan juga unsur klimatologi. Hujan adalah hydrometeor yang jatuh berupa partikel-partikel air yang mempunyai diameter $0,5 \mathrm{~mm}$ atau lebih. Hydrometeor yang jatuh ke tanah disebut hujan sedangkan yang tidak sampai tanah disebut Virga (Tjasyono, 2013). Hujan yang sampai ke permukaan tanah dapat diukur dengan jalan mengukur tinggi air hujan tersebut dengan berdasarkan volume air hujan per satuan luas. Hasil dari pengukuran tersebut dinamakan dengan curah hujan. Curah hujan merupakan salah satu unsur cuaca yang datanya diperoleh dengan cara mengukurnya dengan menggunakan alat penakar hujan, sehingga dapat diketahui jumlahnya dalam satuan millimeter $(\mathrm{mm})$. Curah hujan $1 \mathrm{~mm}$ adalah jumlah air hujan yang jatuh di permukaan per satuan luas $\left(\mathrm{m}^{2}\right.$ ) dengan catatan tidak ada yang menguap, meresap atau mengalir. Jadi, curah hujan sebesar $1 \mathrm{~mm}$ setara dengan 1 liter $/ \mathrm{m}^{2}$ ( Aldrian et al., 2011).

Salinitas adalah berat garam dalam gram per kilogram air laut serta merupakan ukuran keasinan air laut dengan satuan pro mil $(\%$ o). Salinitas menggambarkan padatan total di dalam air, setelah semua karbonat dikonversi menjadi oksida, semua bromida dan iodida digantikan oleh klorida, dan semua bahan organik. Nilai salinitas perairan laut biasanya $30 \%-40 \%$. Pada perairan hipersalin, nilai salinitas dapat mencapai kisaran $40 \%-80 \%$. Pada perairan pesisir, nilai salinitas sangat dipengaruhi oleh masukan air tawar dari sungai (Hartami, 2008). Salinitas adalah faktor yang penting dalam menyusun ekosistem estuari (McLeod and Wing, 2008).

Menurut Anggoro (2000), salinitas berhubungan erat dengan osmoregulasi hewan air, apabila terjadi penurunan salinitas secara mendadak dan dalam kisaran yang cukup besar, maka akan menyulitkan hewan dalam pengaturan osmoregulasi tubuhnya sehingga dapat menyebabkan kematian. Disamping itu, salinitas air merupakan variabel yang berpengaruh langsung terhadap osmolalitas media dan osmoregulasi hewan air.

Salinitas merupakan bagian terpenting untuk membatasi ekspansi distribusi berbagai spesies kekerangan. Spesies kerang hijau atau Perna viridis memiliki rentang toleransi salinitas yang luas, menyebabkan distribusi dari spesies ini dapat menjangkau perairan yang luas (Spinuzzi et al., 2013). Studi yang dilakukan pada kekerangan menunjukkan bahwa kerang memiliki daya tahan yang kuat terhadap salinitas yang berfluktuasi (Guo et al., 2015).

Kelangsungan hidup organisme dipengaruhi oleh keseimbangan antara kandungan ion cairan tubuh dengan kandungan ion dari lingkungannya. Apabila gradien osmotik antara cairan tubuh dengan media lingkungannya terlalu tinggi, maka akan menyebabkan proses fisiologis terganggu, stress bahkan dapat menyebabkan kematian (mortalitas) (Porchase et al., 2009).

Kerang bertahan hidup dalam perbedaan osmotik lingkungan dengan cara menutup cangkangnya sangat rapat selama kondisi lingkungan yang merugikan. Ketika membeli kerang di pasar ikan. Setiap kerang yang masih hidup menutup cangkang sangat rapat, menunggu sampai kondisi lingkungan yang lebih baik. Ini sangat penting bahwa kerang dapat mengunci dari lingkungan yang kering sebagai mana kerang mempunyai kapasitas yang rengah dalam menjaga gradient osmotik antara lingkungan luar dan cairan selnya (Timothy, 2009).

Laju pertumbuhan atau growth rate adalah sebuah pengukuran secara menyeluruh tentang performa yang mana mudah untuk diinterpretasi (menguntungkan ketika meningkat atau merugikan ketika menurun) dan pertumbuhan berkaitan dengan tingkat kelahiran dan kematian. Hal ini dapat memiliki pengaruh penting pada struktur populasi dan komunitas (Scarlet et al., 2015). Laju pertumbuhan kerang hijau (Perna viridis) bergantung kepada pasokan energi dan proses metabolisme tubuh. Salinitas, kandungan oksigen terlarut dan temperatur media memiliki hubungan dengan pertumbuhan kerang hijau (Yutaka, 2015).

Salinitas merupakan faktor ekologi penting yang mempengaruhi distribusi, kelimpahan dan fisiologi umum dari organisme air. Akibatnya perubahan salinitas lingkungan berhubungan langsung dengan kapasitas osmoregulasi pada organisme air. Osmoregulasi adalah proses fisiologis penting bagi organisme air untuk mengatasi perbedaan antara konsentrasi ion dalam tubuh dan linkungan eksternal dan mempertahankan kelangsungan hidup organisme yang normal (Romano and Zeng, 2012).

Ketika salinitas menurun, kerang hijau dapat mengalami stres osmotik pada daerah estuari dan pesisir, sehingga mengharuskan mengeluarkan energi tambahan untuk menjaga osmolaritas dari cairan tubuh (haemolymph) diatas dari osmolaritas lingkungan eksternal (Youji, 2013).

Perubahan pada kadar salinitas dapat menyebabkan osmotic shock dalam kerang, terutama pada salinitas yang terjadi penurunan salinitas mendadak dalam 30 sampai dengan $15 \%$. Produksi bisus yang berkurang pada salinitas yang menurun menunjukkan bahwa energi sedang dihabiskan untuk proses - proses lainnya, seperti kontrol osmotik (Wang et al., 2011). 
Menurut Anggoro (2013a), pertumbuhan organisme akuatik terbesar dan efisiensi pemanfaatan pakan tertinggi berada pada kondisi isoosmotik, di mana kandungan ion-ion dalam tubuh organisme akuatik setara dengan media hidupnya sehingga energi untuk aktivitas osmoregulasi kecil dan sisa porsi energi yang lebih besar dapat digunakan untuk pertumbuhan.

\section{MATERI DAN METODE PENELITIAN}

\section{Materi Penelitian}

Materi yang digunakan pada penelitian ini adalah kerang hijau (Perna viridis) yang berasal dari perairan Tambak Lorok Semarang dan sampel air tambak. Alat yang digunakan dalam penelitian ini adalah jaring digunakan untuk wadah kultivasi sampel kerang hijau, Automatic micro-osmometer roebling digunakan untuk mengukur osmolaritas air dan haemolymph kerang hijau, timbangan elektrik ketelitian 0,01 gram digunakan untuk mengukur berat kerang hijau, termometer digunakan untuk mengukur temperatur, refraktometer digunakan untuk mengukur salinitas, cool box digunakan untuk menyimpan sampel kerang hijau dan media, botol PE digunakan untuk menyimpan sampel air, $\mathrm{pH}$ paper digunakan untuk mengukur $\mathrm{pH}$ media, spuit suntik digunakan untuk mengambil cairan tubuh kerang hijau. Botol Winkler digunakan untuk wadah sampel air dalam analisis oksigen terlarut. Buret digunakan untuk wadah titrasi dalam analisis oksigen terlarut. Pipet digunakan untuk mengambil reagen. Bahan yang digunakan dalam penelitian ini adalah kerang hijau yang memiliki berat 40 gram/ekor, sampel air tambak dan reagen untuk analisis oksigen terlarut antara lain $\mathrm{MnSO}_{4}, \mathrm{H}_{2} \mathrm{SO}_{4}, \mathrm{NaOH}$ dalam KI, $\mathrm{N}_{2} \mathrm{~S}_{2} \mathrm{O}_{3}$ dan amilum.

\section{Metode Penelitian}

Penelitian ini dilakukan di lapangan dengan menggunakan metode korelasi. Penelitian korelasi atau korelasional adalah suatu penelitian untuk mengetahui hubungan dan tingkat hubungan antara dua variabel atau lebih tanpa ada upaya untuk mempengaruhi variabel tersebut sehingga tidak terdapat manipulasi variabel (Fraenkel dan Wallen, 2008). Metode penelitian ini digunakan untuk mengetahui hubungan antara tingkat kerja osmotik dengan laju pertumbuhan kerang hijau yang dikultivasi di perairan Tambak Lorok, Semarang.

\section{Penentuan Data Sampel}

Penentuan lokasi stasiun ditentukan menggunakan metode "Purposive Sampling". Menurut Sugiyono (2012), purposive sampling adalah teknik penentuan sampel dengan pertimbangan tertentu. Stasiun pengambilan kerang hijau berupa bagan yang merupakan tempat budidaya kerang hijau di perairan Tambak Lorok, Semarang. Stasiun pengambilan berjumlah 3 stasiun. Penentuan stasiun berdasarkan pada wilayah yang diperkirakan telah mewakili perairan Tambak Lorok yaitu bagian perbatasan dengan wilayah perairan disebelah barat dan timur serta wilayah di tengah dari perairan Tambak Lorok. Pengambilan data kerang hijau dilakukan dalam dua tahap. Tahap pertama pada tanggal 20 September 2016 dan tahap kedua pada tanggal 18 November 2016. Pengambilan data kerang hijau pada tahap pertama memiliki berat rata-rata sebesar 40 gram. Kerang hijau pada setiap stasiunnya diambil lima ekor setiap tahapnya. Data curah hujan pada lokasi sampling di perairan Tambak Lorok Semarang menggunakan data curah hujan harian dari Stasiun Klimatologi Semarang. Pengukuran parameter kualitas air selama kultivasi kerang hijau dilakukan pada awal dan akhir penelitian. Parameter kualitas air yang diukur antara lain salinitas, temperatur, oksigen terlarut, $\mathrm{pH}$, arus.

\section{Pengambilan Data Tingkat Kerja Osmotik}

Nilai tingkat kerja osmotik kerang hijau didapatkan dengan menggunakan automatic micro-osmoter roebling. Tingkat kerja osmotik didapatkan dengan mengukur osmolaritas media dan haemolymph. Pengukuran pada osmolaritas haemolymph, terlebih dahulu kerang hijau dibunuh dan diambil haemolymphnya sebanyak $0,01 \mathrm{ml}$ serta media kultivasi kemudian dimasukkan kedalam microtube. Haemolymph yang sudah terkumpul lalu dilakukan pengukuran dengan automatic micro-osmoter roebling. Nilai osmolaritas akan ditampilkan pada alat tersebut.

Tingkat Kerja Osmotik (TKO)

Tingkat Kerja Osmotik (TKO) dihitung berdasarkan selisih nilai osmolaritas haemolymph kerang hijau dengan osmolaritas media. Perhitungan Tingkat Kerja Osmotik atau TKO menggunakan persamaan dari Anggoro dan Nakamura (2005), sebagai berikut :

$$
\mathrm{TKO}=[\mathrm{P} \text { osmo haemolymph }-\mathrm{P} \text { osmo media }]
$$

Keterangan :

TKO : tekanan kerja osmotik $\left(\mathrm{mOsm} / \mathrm{l} \mathrm{H}_{2} \mathrm{O}\right)$

$\mathrm{P}$ osmo haemolymph : tekanan osmotik cairan tubuh $\left(\mathrm{mOsm} / 1 \mathrm{H}_{2} \mathrm{O}\right)$

P osmo media : tekanan osmotik/ osmolaritas media

$$
\text { [ ] : nilai mutlak }
$$

\section{Laju Pertumbuhan Relatif (RGR)}

Laju pertumbuhan relatif kerang hijau ditentukan dengan cara mengukur berat kerang hijau pada awal penelitian dan akhir penelitian. Laju pertumbuhan relatif dihitung berdasarkan persamaan Effendi (2002), sebagai berikut :

$$
\mathrm{RGR}=\frac{W t-W 0}{w 0} x 100 \%
$$


Keterangan:

RGR : laju pertumbuhan relatif ( $\%)$

W0 : berat kerang hijau pada awal penelitian (g)

Wt : berat kerang hijau pada akhir penelitian (g)

\section{Analisis Data}

Pengolahan data dilakukan dengan menggunakan analisis regresi untuk mengetahui hubungan salinitas media dengan tingkat kerja osmotik dan tingkat kerja osmotik dengan laju pertumbuhan relatif dari kerang hijau yang dikultivasi di perairan Tambak Lorok, Semarang. Alat bantu yang digunakan melaksanakan uji statistik adalah program Microsoft Excel 2013. Parameter kualitas air yang diperoleh dalam penelitian dianalisis secara deskriptif.

\section{HASIL DAN PEMBAHASAN}

\section{Pola Osmoregulasi, Haemolymph dan Osmolaritas Media}

Hasil pengukuran osmolaritas media dan haemolymph kerang hijau disajikan pada Tabel 1 dan 2

Tabel 1. Data osmolaritas media dan haemolymph kerang hijau pertama

\begin{tabular}{|c|c|c|c|c|}
\hline \multirow[t]{2}{*}{ Stasiun } & \multirow{2}{*}{$\begin{array}{c}\text { Salinitas } \\
(\%)\end{array}$} & \multicolumn{2}{|c|}{ Osmolaritas $\left(\mathrm{mOsm} / \mathbf{l} \mathrm{H}_{2} \mathrm{O}\right)$} & \multirow[t]{2}{*}{ Pola Osmoregulasi } \\
\hline & & Media & Haemolymph & \\
\hline $\mathrm{I}$ & 28 & $544,78 \pm 0,04$ & $580,21 \pm 0,56$ & Hiperosmotik \\
\hline II & 27 & $525,74 \pm 0,39$ & $572,30 \pm 0,41$ & Hiperosmotik \\
\hline III & 27 & $525,36 \pm 0,09$ & $572,6 \pm 0,31$ & Hiperosmotik \\
\hline
\end{tabular}

Sumber: Hasil Penelitian (2016)

Tabel 2. Data osmolaritas media dan haemolymph kerang hijau kedua

\begin{tabular}{ccccc}
\hline Stasiun & Salinitas & \multicolumn{2}{c}{ Osmolaritas $(\mathbf{m O s m} / \mathbf{l ~ H 2 O )}$} & Pola Osmoregulasi \\
\cline { 3 - 4 } & $\mathbf{( \% )}$ & Media & Haemolymph & \\
\hline I & 27 & $525,29 \pm 0,01$ & $572,01 \pm 0,04$ & Hiperosmotik \\
II & 27 & $525,28 \pm 0,01$ & $572,02 \pm 0,05$ & Hiperosmotik \\
III & 26 & $502 \pm 0,02$ & $570,03 \pm 0,05$ & Hiperosmotik \\
\hline
\end{tabular}

Sumber: Hasil Penelitian (2016)

Berdasarkan hasil pengukuran bahwa nilai osmolaritas haemolymph dari kerang hijau di semua stasiun memiliki nilai lebih tinggi jika dibandingkan dengan nilai osmolaritas media selama kultivasi. Respon osmotik kerang hijau pada semua stasiun selama proses kultivasi bersifat hiperosmotik, yaitu melakukan penyesuaian konsentrasi cairan tubuh yang lebih tinggi dari konsentrasi media melalui mekanisme osmoregulasi dalam menyeimbangkan tekanan osmotik di dalam dan di luar tubuh.

\section{Kandungan Elektrolit dan Osmolaritas Media}

Hasil pengukuran kandungan elektrolit, salinitas dan osmolaritas dari media kultivasi kerang hijau disajikan pada Tabel 3.

Tabel 3. Data kandungan elektrolit, salinitas dan osmolaritas media kultivasi

\begin{tabular}{|c|c|c|c|c|c|c|c|c|}
\hline \multirow[b]{2}{*}{ Pengambilan } & \multirow[b]{2}{*}{ Stasiun } & \multicolumn{5}{|c|}{ Kandungan Elektrolit (g/kg) } & \multirow{2}{*}{$\begin{array}{c}\text { Salinitas } \\
(\% \%)\end{array}$} & \multirow{2}{*}{$\begin{array}{c}\text { Osmolaritas } \\
\text { Media } \\
\text { mOSM/l H } \\
\end{array}$} \\
\hline & & $\mathbf{N a}^{+}$ & $\mathrm{Cl}^{-}$ & $\mathrm{Ca}^{2+}$ & $\mathrm{Mg}^{2+}$ & $\mathbf{K}^{+}$ & & \\
\hline \multirow[t]{3}{*}{1} & $\mathrm{I}$ & 7,6 & 15,6 & 2 & 1,98 & 0,8 & 28 & $544,78 \pm 0,04$ \\
\hline & II & 7,3 & 15,04 & 1,92 & 1,92 & 0,77 & 27 & $525,74 \pm 0,39$ \\
\hline & III & 7,3 & 15,04 & 1,92 & 1,91 & 0,77 & 27 & $525,36 \pm 0,09$ \\
\hline \multirow[t]{3}{*}{2} & I & 7,3 & 15,04 & 1,93 & 1,91 & 0,78 & 27 & $525,29 \pm 0,01$ \\
\hline & II & 7,32 & 15,04 & 1,92 & 1,92 & 0,78 & 27 & $525,28 \pm 0,01$ \\
\hline & III & 7,3 & 15,02 & 1,91 & 1,9 & 0,76 & 26 & $502 \pm 0,02$ \\
\hline
\end{tabular}

Sumber: Hasil Penelitian (2016)

Hasil pengukuran kandungan elektrolit media kultivasi bahwa kandungan elektrolit terbesar pada stasiun pertama dipengambilan pertama dengan nilai salinitas dan osmolaritas media tertinggi, sedangkan kandungan elektrolit terendah media kultivasi terdapat pada stasiun ketiga pada pengambilan kedua yang memiliki nilai salinitas dan osmolaritas media terendah. Menurut Karim (2007), osmolaritas media semakin besar dengan peningkatan salinitas, hal tersebut disebabkan peningkatan konsentrasi ion-ion terlarut. Sifat osmotik dari media bergantung pada seluruh ion yang terlarut di dalam media tersebut. Dengan semakin besarnya jumlah ion terlarut di dalam media, tingkat kepekaan osmolaritas larutan akan semakin tinggi pula, sehingga akan menyebabkan semakin bertambah besarnya tekanan osmotik media. Curah Hujan dan Salinitas

Hasil perhitungan hubungan atau persamaan curah hujan dan salinitas disajikan pada kurva sebagai berikut 


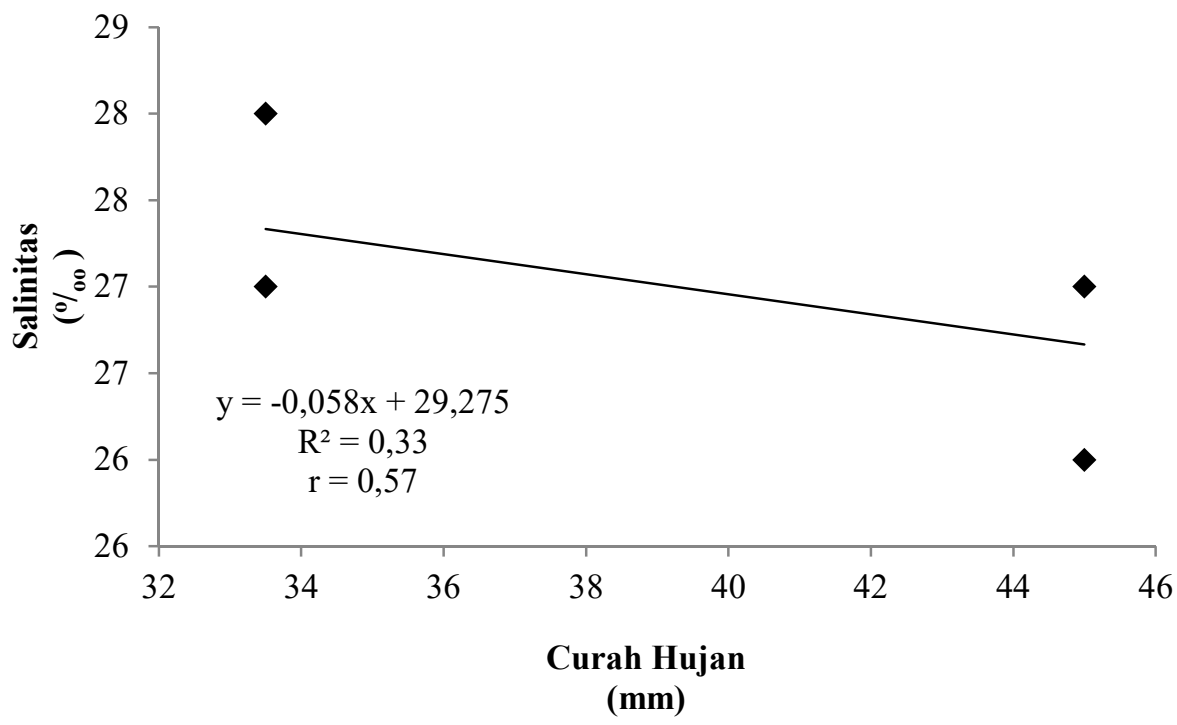

Gambar 1. Hubungan antara curah hujan dan salinitas di lokasi sampling

Berdasarkan hubungan antara curah hujan dan salinitas di lokasi sampling di atas didapatkan persamaan sebagai berikut :

Keterangan :

$$
y=-0,058 x+29,275 \text { dengan nilai } R^{2}=0,33 \text { dan } r=0,57
$$

$\mathrm{x}$ : curah hujan

$\mathrm{y}:$ salinitas

Persamaan di atas dengan variabel bebas (x) yaitu curah hujan dan variabel tidak bebas atau terikat (y) yaitu salinitas dapat diketahui nilai $\mathrm{r}$ yang diperoleh sebesar 0,57. Angka koefisien korelasi ini menerangkan bahwa curah hujan mempunyai korelasi atau pengaruh yang sebesar 57\% terhadap salinitas perairan. Nilai koefisien determinasi $\left(\mathrm{R}^{2}\right)$ $=0,33$ menunjukkan bahwa curah hujan berpengaruh terhadap salinitas perairan sebesar $33 \%$.

Salinitas dan Tingkat Kerja Osmotik

Hasil perhitungan tingkat kerja osmotik kerang hijau pada pengambilan pertama dan kedua disajikan sebagai berikut Tabel 4. Data tingkat kerja osmotik kerang hijau

\begin{tabular}{cccc}
\hline Stasiun & Salinitas $\mathbf{( \% o})$ & Tingkat Kerja Osmotik (mOsm/ $\mathbf{~ H 2} \mathbf{O})$ & Pengambilan \\
\hline 1 & 28 & $35,44 \pm 0,52$ & 1 \\
2 & 27 & $46,57 \pm 0,36$ & \\
3 & 27 & $47,24 \pm 0,24$ & 2 \\
\hline 1 & 27 & $46,71 \pm 0,04$ & \\
3 & 27 & $46,74 \pm 0,05$ & \\
\hline
\end{tabular}

Sumber: Hasil Penelitian (2016)

Hasil pengukuran yang diperoleh dalam penelitian menunjukkan nilai salinitas dengan kisaran 26 - $27 \%$ selama kultivasi. Perubahan salinitas yang terjadi pada media selama kultivasi berpengaruh terhadap nilai osmolaritas media yang mengharuskan kerang hijau untuk melakukan proses osmoregulasi yang berpengaruh pada tingkat kerja osmotik kerang hijau. Berdasarkan hasil perhitungan tingkat kerja osmotik pada tabel 6 diketahui bahwa nilai tingkat kerja osmotik tertinggi berada pada salinitas $26 \%$ dengan nilai $68,03 \mathrm{mOsm} / 1 \mathrm{H}_{2} \mathrm{O}$ dan nilai tingkat kerja osmotik terendah pada salinitas $28 \%$ o dengan nilai $35,44 \mathrm{mOsm} / \mathrm{l} \mathrm{H}_{2} \mathrm{O}$. Kondisi yang mendekati isoosmotik (seimbang) pada media dengan salinitas $28 \%$ o terlihat dari rendahnya perbedaan antara osmolaritas media dan osmolaritas haemolymph sehingga tingkat kerja osmotik menjadi rendah. Menurut Suharyanto dan Tjaronge (2009), salinitas air sangat berpengaruh terhadap tekanan osmotik air, semakin tinggi salinitas semakin tinggi pula tekanan osmotik di lingkungan. 


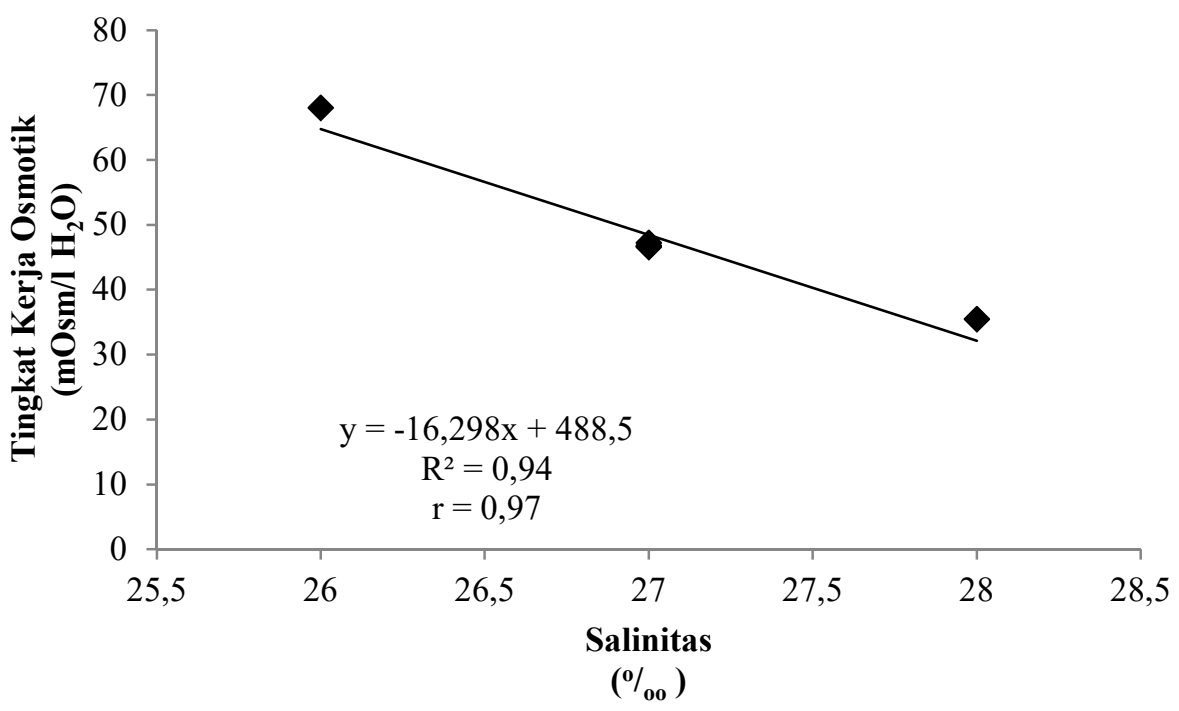

Gambar 3. Hubungan antara salinitas media dengan tingkat kerja osmotik kerang hijau

Berdasarkan hubungan antara salinitas media dengan tingkat kerja osmotik kerang hijau di atas didapatkan persamaan sebagai berikut :

$$
y=-16,298 x+488,5 \text { dengan nilai } R^{2}=0,94 \text { dan } r=0,97
$$

Keterangan :

$\mathrm{x}$ : salinitas

$\mathrm{y}$ : tingkat kerja osmotik

Persamaan di atas dengan variabel bebas (x) yaitu salinitas dan variabel tidak bebas atau terikat (y) yaitu tingkat kerja osmotik dapat diketahui nilai $\mathrm{r}$ yang diperoleh sebesar 0,97. Angka koefisien korelasi ini menerangkan bahwa salinitas mempunyai korelasi atau pengaruh yang kuat sebesar 97\% terhadap tingkat kerja osmotik kerang hijau. Nilai koefisien determinasi $\left(\mathrm{R}^{2}\right)=0,94$ menunjukkan bahwa salinitas media berpengaruh terhadap tingkat kerja osmotik sebesar $94 \%$.

Menurut Anggoro et al., (2013b) organisme yang hidup pada kondisi lingkungan yang mendekati isoosmotik akan memerlukan sedikit energi untuk osmoregulasi dibandingkan pada kondisi yang hipoosmotik maupun hiperosmotik. Energi yang digunakan dalam proses osmoregulasi kecil maka alokasi energi untuk pertumbuhan akan lebih besar sehingga organisme akan tumbuh lebih optimal. Hasil perhitungan tingkat kerja osmotik kerang hijau terlihat bahwa semakin menjauhi media isoosmotik maka tingkat kerja osmotik semakin tinggi, menyebabkan konsumsi energi untuk osmoregulasi yang lebih dari saat kondisi media isoosmotik.

Laju Pertumbuhan Relatif (RGR)

Hasil pengukuran laju pertumbuhan relatif (RGR) kerang hijau selama kultivasi disajikan pada Tabel 5 Tabel 5. Data laju pertumbuhan relatif (RGR) kerang hijau selama kultivasi

\begin{tabular}{|c|c|c|c|c|c|c|}
\hline Stasiun & & La & umbuha & $(\%)$ & & Rerata \pm SD \\
\hline 1 & 199,30 & 201,07 & 222,42 & 236,58 & 244,08 & $220,69 \pm 20,28$ \\
\hline 2 & 171,31 & 181,60 & 197,59 & 198,24 & 202,05 & $190,16 \pm 13,14$ \\
\hline 3 & 116,45 & 122,63 & 133,45 & 143,96 & 150,15 & $133,33 \pm 14,10$ \\
\hline
\end{tabular}

Sumber: Hasil Penelitian (2016)

Hasil laju pertumbuhan relatif yang didapatkan selama penelitian yang dikultivasi selama 60 hari menunjukkan bahwa rata-rata laju pertumbuhan relatif di stasiun pertama sebesar 220,69\%, stasiun kedua sebesar 190,16\% dan stasiun ketiga sebesar 133,33\%. Nilai laju pertumbuhan relatif tertinggi berada pada stasiun pertama, hal ini diduga berkaitan dengan tingkat kerja osmotik yang rendah, sehingga energi yang digunakan untuk proses osmoregulasi kecil dan sisa energi tersebut dapat digunakan untuk pertumbuhan dengan tinggi, sedangkan nilai laju pertumbuhan relatif terendah berada pada stasiun ketiga, diduga berkaitan dengan tingkat kerja osmotik yang tinggi, hal ini mengakibatkan keperluan energi untuk proses osmoregulasi yang besar menyebabkan energi untuk pertumbuhan yang rendah.

\section{Hubungan antara Tingkat Kerja Osmotik dan Laju Pertumbuhan Relatif}

Bentuk hubungan atau permasaan dari tingkat kerja osmotik terhadap laju pertumbuhan relatif kerang hijau tersaji pada Gambar 4. 


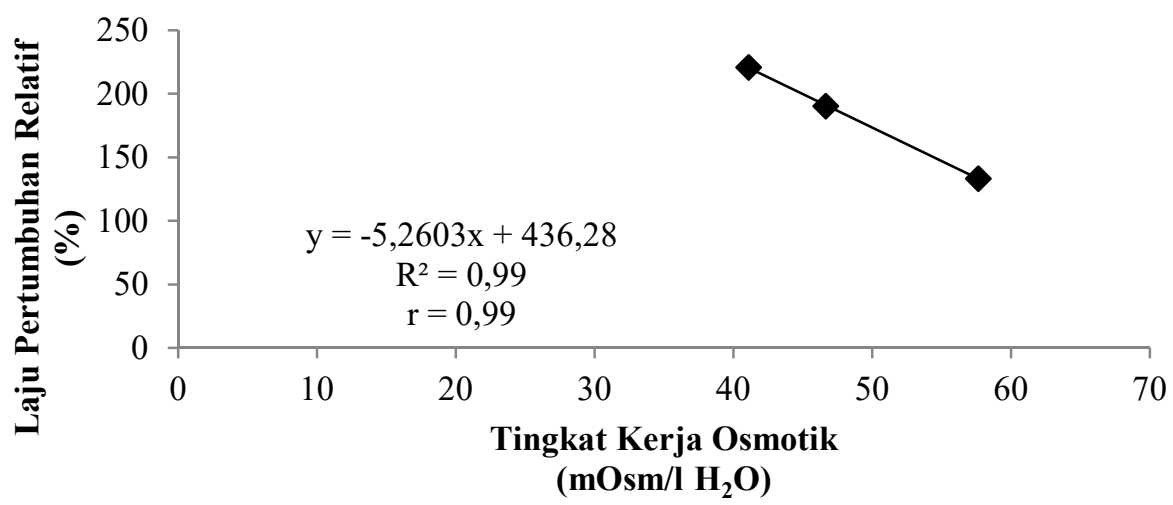

Gambar 4. Hubungan antara tingkat kerja osmotik dengan laju pertumbuhan relatif kerang hijau

Berdasarkan hubungan antara tingkat kerja osmotik dengan laju pertumbuhan relatif kerang hijau di atas didapatkan persamaan sebagai berikut :

$$
y=-5,2603 x+436,28 \text { dengan nilai } R^{2}=0,99 \text { dan } r=0,99
$$

Keterangan :

$\mathrm{x}$ : tingkat kerja osmotik $\left(\mathrm{mOsm} / 1 \mathrm{H}_{2} \mathrm{O}\right)$

$\mathrm{y}$ : laju pertumbuhan relatif $(\%)$

Persamaan di atas dengan variabel bebas (x) yaitu tingkat kerja osmotik dan variabel tidak bebas atau terikat (y) yaitu laju pertumbuhan relatif dapat diketahui nilai $\mathrm{r}$ yang diperoleh sebesar 0,99. Angka koefisien korelasi ini menerangkan bahwa tingkat kerja osmotik mempunyai korelasi atau pengaruh yang kuat sebesar 99\% terhadap laju pertumbuhan relatif. Nilai koefisien determinasi $\left(\mathrm{R}^{2}\right)=0,99$ menunjukkan bahwa tingkat kerja osmotik berpengaruh terhadap laju pertumbuhan relatif sebesar $99 \%$.

Berdasarkan data yang didapatkan selama penelitian kerang hijau melakukan proses osmoregulasi yang berbeda pada setiap stasiunnya hal ini diduga karena adanya perbedaan salinitas sehingga osmolaritas media pun berbeda. Tingkat kerja osmotik kerang hijau menunjukkan bahwa proses osmoregulasi berjalan.

Proses osmoregulasi ini memerlukan banyak energi untuk menyeimbangkan cairan tubuh dengan cairan lingkungan. Energi yang digunakan untuk pertumbuhan kemudian dialihkan untuk digunakan dalam proses osmoregulasi ini sehingga mengakibatkan laju pertumbuhan yang terhambat. Kondisi salinitas dalam keadaan isoosmotik maka pertumbuhan akan berjalan optimum, dikarenakan energi yang digunakan untuk pertumbuhan lebih banyak.

\section{Kualitas Air}

Hasil pengukuran parameter kualitas air yang dilakukan antara lain salinitas $(\%$ oo $), \mathrm{DO}(\mathrm{mg} / \mathrm{l})$, temperatur $\left({ }^{\circ} \mathrm{C}\right)$, $\mathrm{pH}$ dan arus $(\mathrm{cm} / \mathrm{dt})$. Data pengukuran kualitas air selama proses kultivasi kerang hijau disajikan pada Tabel 6.

Tabel 6. Data pengukuran kualitas air selama kultivasi

\begin{tabular}{lccl}
\hline \multicolumn{1}{c}{ Parameter } & Hasil Pengukuran & Nilai Optimum & \multicolumn{1}{c}{ Sumber } \\
\hline Salinitas $(\%$ oo & $26-28$ & $25-35$ & Putra, 2006 \\
Temperatur $\left({ }^{\circ} \mathrm{C}\right)$ & $28-33$ & $27-37$ & Rukmana, 2004 \\
DO $(\mathrm{mg} / \mathrm{l})$ & $1,4-5,7$ & $5,5-6,0$ & Putra, 2006 \\
$\mathrm{pH}$ & $6,0-7$ & $6,0-8,2$ & Yonvitner, 2001 \\
Arus $(\mathrm{cm} / \mathrm{dt})$ & $0-13$ & $10-30$ & Porsepwandi, 1998 \\
\hline
\end{tabular}

Sumber: Hasil Penelitian (2016)

\section{KESIMPULAN}

Kesimpulan yang dapat diambil dari penelitian ini adalah sebagai berikut :

1. Kerang hijau yang dikultivasi selama penelitian bertipe osmoregulator dengan pola osmoregulasi hiperosmotik terhadap media eksternal.

2. Tingkat kerja osmotik dari kerang hijau selama kultivasi sebesar 35,44 sampai dengan $68,03 \mathrm{mOsm} / 1 \mathrm{H}_{2} \mathrm{O}$.

3. Laju pertumbuhan relatif dari kerang hijau selama kultivasi sebesar $133,33 \%$ sampai dengan $220,69 \%$.

4. Hubungan tingkat kerja osmotik dengan laju pertumbuhan relatif kerang hijau berpola linier bersifat negatif dengan tingkat keeratan tinggi. 


\section{UCAPAN TERIMA KASIH}

Penulis menyampaikan ucapan terima kasih kepada Prof. Dr. Sahala Hutabarat dan Dr. Ir. Abdul Ghofar, M.Sc yang telah membantu dan memberikan bimbingan dalam penelitian serta semua pihak yang telah membantu terlaksananya penelitian sampai dengan selesai.

\section{DAFTAR PUSTAKA}

Aldrian, E., Budiman, dan Mimin, K. 2011. Adaptasi dan Mitigasi Perubahan Iklim di Indonesia. Pusat Perubahan Iklim dan Kualitas Udara Kedeputian Bidang Klimatologi, Badan Meteorologi, Klimatologi dan Geofisika. Jakarta.

Amalia, 2007. Pemanfaatan Kerang Hijau (Mytilus viridis) dalam Pembuatan Hidrolisat Protein Menggunakan Enzim Papain.

Anggoro, S. 2000. Pola Regulasi Osmotik dan Kerja Enzim Na-K-Atpase Udang Windu (Penaeus Monodon Fabr.) pada Berbagai Fase Molting. Aquaculture Indonesia, 1(2): 15-20.

, and Nakamura, K. 2005. Osmotic Response and Feeding Pattern of Kuruma Shrimp (Penaeus japonicus) at Various Molting Stages. Research Report. Lab. of Propagation Physiology. Scientific article 11. Fisheries Fac. Kagoshima University, Kagoshima.

, Rudiyanti., dan Rahmawati. 2013a. Domestikasi Ikan Kerapu Macan (Epinephelus fuscoguttatus) melalui Optimasimalisasi Media Pakan. Journal of Management of Aquatic Resources, 2(3): 119-127.

Subiyanto, dan Rahmawati, Y.A. 2013b. Domestikasi Lobster Air Tawar (Cherax quadricarinatus) melalui Optimalisasi Media dan Pakan. Journal of Management of Aquatic Resources, 2(3): 128-137.

Effendi, M.I. 2002 Biologi Perikanan. Yayasan Pustaka Nusantara, Jakarta, 163 hlm.

Fraenkel, J.P. dan Wallen, N. E. 2008. How to Design and Evaluate Research in Education. McGrow-Hill Companies, Inc, New York.

Guo X.M., He Y, Zhang L.L., Lelong, C., Jouaux, A. 2015. Immune and Stress Responses in Oysters with Insights on Adaptation. Fish Shellfish Immunol, 46:107-119.

Hartami, P. 2008. Analisis Wilayah Perairan Teluk Pelabuhan Ratu untuk Kawasan Budidaya Perikanan Sistem Keramba Jaring Apung. [Tesis]. Program Pascasarjana, Institut Pertanian Bogor, Bogor.

Karim, M. 2007. Pengaruh Salinitas dan Bobot terhadap Konsumsi Kepiting Bakau (Scylla serrata Forsskal). J.Sains \& Teknologi, 7(2): 85-92.

McLeod, R and Wing, S. 2008. Influence of An Altered Salinity Regime on the Population Structure of Two Infaunal Bivalve Species. Estuar. Coast. Shelf Sci, 78: 529-540.

Porchase, MM., Luis, R., Martines, C., and Ramos, R. 2009. Cortisol and Glucose Reliable indicator of Fish. American Journal of Aquatic Sciences, 4(2): 157-178

Putra, W.S. 2006. Laju Filtrasi Kerang Hijau (Perna viridis L. 1758) dalam Mereduksi Bahan Tersuspensi. Fakultas Perikanan dan Ilmu Kelautan. Institut Pertanian Bogor, 89 hlm.

Putri, L. dan Aunurohim, A. 2012. Kecepatan Filtrasi Kerang Hijau (Perna viridis) terhadap Chaetocheros sp. dalam Media Logam Tercemar Kadmium. Jurnal Sains dan Seni. Institut Teknik Surabaya, Surabaya

Romano, N. and Zeng, C.S. 2012. Osmoregulation in Decapod Crustaceans: Implications to Aquaculture Productivity, Methods for Potential Improvement and Interactions with Elevated Ammonia Exposure. Aquaculture, 334: 1223.

Rukmana, R. 2004. Budi Daya Kerang Hijau. Aneka Ilmu. Semarang, 42 hlm.

Scarlet, M.P.J., Halldórsson, H.P., Granmo, Åke. 2015. Scope for Growth and Condition Index in the Clam Meretrix meretix (L.) as Biomarkers of Pollution in Espírito Santo Estuary, Mozambique. Regional Studies in Marine Science, 1: 63-71. 
Spinuzzi S., Schneider K.R., Walters L.J., Yuan W.S., and Hoffman E.A. 2013. Tracking The Distribution of NonNative Marine Invertebrates (Mytella charruana, Perna viridis and Megabalanus coccopoma) Along The SouthEastern USA. Marine Biodiversity Records. 6(55): 1-13.

Sugiyono. 2012.Metode Penelitian Bisnis. Alfabeta, Bandung, 540 hlm.

Suharyanto dan M. Tjaronge. 2009. Pertumbuhan dan Sintasan Krablet Rajungan (Portunus pelagicus) pada Salinitas yang Berbeda. Jurnal Ichthyos. 8(1): 7-12.

Timothy, J. B. 2009. Animal Osmoregulation. OABS, Oxford University Press. UK, pp 224.

Tjasyono, B., dan Efendi, D. 2013. Ilmu Kebumian dan Antariksa. PT Remaja Rosdakarya, Bandung, 215 hlm.

Wang, Y.J., Hu, M.H., Wong, W.H., Shin, P.K.S. and Cheung, S.G. 2011. The Combined Effects of Oxygen Availability and Salinity on Physiological Responses and Scope for Growth in the Green-Lipped Mussel Perna viridis. Marine Pollution Bulletin, 63: 255-261.

Yonvitner. 2001. Struktur Komunitas Makrozoobentor dan Pertumbuhan Kerang Hijau (Perna viridis L) di Perairan Muara Kamal dan Bojonegoro. [Tesis]. Program Pascasarjana. Institut Pertanian Bogor, Bogor.

, dan Sutrisno, S. 2009. Laju Pertumbuhan dan Penempelan Kerang Hijau (Perna viridis, Linn, 1789) Jurnal Ilmiah Pendidikan Biologi (Biologi Edukasi), 1(2): 44-49.

Youji W., Menghong, H., Siu, G.C., Paul, K.S.S., Weiqun, L. and Jiale, L. 2013. Antipredatory Responses of Perna viridis (Linnaeus, 1758) Under Acute Hypoxia and Low Salinity. Journal Molluscan Study, 79 (1): $42-50$.

Yutaka, T., Isamu, S., Gyo, I. 2015. Scope for Growth of Mytilus galloprovincialis and Perna viridis as a Thermal Stress Index in the Coastal Waters of Japan: Field Studies at the Uranouchi Inlet and Yokohama. Journal of Experimental Marine Biology and Ecology, 470: 55-63. 